\title{
Bernardo Houssay (1887-1971): Endocrine physiologist and Nobel laureate
}

\author{
Siang Yong $\operatorname{Tan}^{1}$, MD, JD, Nathaniel Ponstein ${ }^{2}$, MD
}

T he pituitary gland influences a myriad of physiologic functions with extraordinary elegance. Shortly after the discovery of insulin, Argentinian science prodigy Bernardo Houssay elucidated the important role of the anterior pituitary, also called the adenohypophysis, in carbohydrate metabolism. This discovery helped to unravel the intricacies of glucose homeostasis and the fascinating feedback servo mechanisms that undergird the entire endocrine system.

TEENAGE SAVANT Bernardo Alberto Houssay was born to Dr Albert and Clara Houssay, both of whom had emigrated from France to Argentina. His father worked as a barrister and his mother was a housewife. From an early age, young Houssay exhibited a formidable aptitude for academics. His intellectual abilities allowed him to accelerate his education, attaining his baccalaureate degree with honours via a scholarship from a well-respected private institution at the tender age of 13. Less than a year later, in 1901, he matriculated at the University of Buenos Aires to pursue an advanced degree in pharmacology. By 1904, he had graduated as valedictorian from this programme and had decided to advance his education to become a physician. Upon

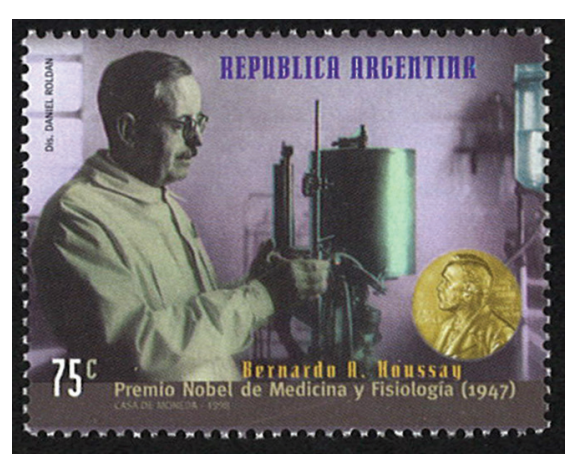

Laboratories in Buenos Aires, pursuing research into snake and insect venoms. This work led to the development of an effective spider antivenom. Before long, in 1915, Houssay assumed the role of chief physician at Alvear Hospital.

Around this time, Houssay found himself at a crossroads in his career. While he enjoyed both clinical medicine and investigative research, he felt that he would be more productive and useful to his country if he focused his ardour on research. In 1919, a 32-year-old Houssay assumed the position of Chair of Physiology at his alma mater, the University of Buenos Aires, and stayed in that position for the next 25 years. What followed was an illustrious career. He quickly transformed the department into an active centre of research that fostered the careers of some of Latin America's most influential scientific figures. In the course of penning over 500 publications, Houssey covered the entire spectrum of human physiology of the endocrine, respiratory and circulatory systems, as well as neurology and immunology.

Some of Houssay's initial research would prove to be his most influential. Following the isolation of insulin by Frederick Banting, Charles Best and other researchers in 1921, Houssay coordinated a concerted effort to further investigate this hormone and others involved in carbohydrate metabolism. At this time, it was established that dogs which had undergone a pancreatectomy were prone to hyperglycaemia, which was presumably secondary to a lack of insulin production. These animals eventually developed diabetes mellitus. Importantly, Houssay found that animals that had undergone hypophysectomy experienced the opposite effect - they were susceptible to hypoglycaemia. In separate animal experiments after hypophysectomy, injection of anterior pituitary extracts induced hyperglycaemia. These observations led to the inescapable conclusion that the adenohypophysis contained one or more antiinsulin, diabetogenic principles. Furthermore, in elegant studies on pancreatectomised animals ('Houssay dogs'), Houssay noted that the induced diabetic state was greatly ameliorated when the adenohypophysis was also removed. Houssay also used toads as his experimental model because of their favourable anatomic accessibility and the ease of selectively removing and extracting anterior pituitary tissue. When he injected the anterior pituitary extracts into euglycaemic toads lacking both the pancreas and the hypophysis, hyperglycaemia supervened. From all of this

${ }^{1}$ Emeritus Professor of Medicine, University of Hawaii, ${ }^{2}$ Research carried out during medical residency, Hawaii Residency Programs, Inc, Honolulu, Hawaii, USA Correspondence: Prof Tan Siang Yong, 2226 Liliha Street, Suite B-104, Honolulu, HI 96817, USA. siang@hawaii.edu 
information, Houssay inferred that carbohydrate metabolism did not depend merely on the action of insulin alone, but also on the feedback and interplay of insulin and additional hormones produced in the anterior pituitary.

It had been previously - and incorrectly - believed that the posterior hypophysis was involved in carbohydrate metabolism. Houssay's work showed that it was actually the adenohypophysis. We now know that growth hormone is the critical hormone involved, although adrenocorticotropic hormone, thyroidstimulating hormone and other hormones may also play some role. Houssay's discovery was monumental in establishing a more precise understanding of carbohydrate metabolism and the pathophysiology of diabetes mellitus. Most importantly, this work was catalytic in shifting general endocrine research toward the unravelling of hormonal feedback loops. For his discovery of the part played by the hormone of the anterior pituitary lobe in the metabolism of sugar, Houssay earned the 1947 Nobel Prize in Medicine, sharing it with Carl and Gerty Cori for their work on glycogen metabolism.

In addition to a robust career of groundbreaking physiology research, which also included studies on the pancreatic secretion of insulin and the hormonal control of fat metabolism, Houssay left a palpable legacy in the education of physicians and physiologists. As the Chair of Physiology, he dedicated a significant amount of time to educating medical students, residents and future physiologists. In his mind, the real importance of his experimental studies was in the teaching of methods and the fostering of a love of science. Many of his former pupils went on to become prominent Latin American academicians in their own right. Two of these disciples, Miguel Rolando Covian and Eduardo Braun-Menéndez, collaborated with Houssay in composing the comprehensive Human Physiology, which quickly became the standard text in physiology in all of Latin America.

THE PRICE OF INTEGRITY Following the 1943 revolution, a military dictatorship assumed power in Argentina. Never one to muzzle his own awareness of what was right, Houssay publicly expressed his dissent with the lack of democracy in his country. As a result, the government stripped him of his university position as well as that of approximately 150 other prominent Argentinian intellects. Although Houssay received numerous offers from prestigious overseas academic institutions, he remained steadfast in his loyalty to Argentina. In a letter to a friend and colleague at Harvard University (translated from Spanish), he wrote: "I intend to continue my work in physiology. I have received large numbers of invitations to work in foreign countries. However, my plan my whole life has been to work hard in scientific research to create a circle of scientists of the highest moral and scientific quality in our country. I have no intention of changing this line of conduct."

Fortunately, proponents of Houssay's cause rallied and independent funding was secured to establish a private laboratory for his work, called the Institute of Biology and Experimental Medicine. In 1955, when Argentina's dictatorship ceased, Houssay was rightfully reappointed to his academic position. In addition to resuming his duties at the University of Buenos Aires, he remained the director of the institute that had endorsed him during his difficult times. He continued his devotion to the scientific progress of Argentina by conceiving, founding and directing the National Council of Scientific and Technical Research in Argentina, an organisation that aimed to nurture scientific careers and endeavours in order to help create and retain national scientific talent. It was a fitting capstone to a patriot whose career was unabashedly dedicated to the advancement of medical science.

AN ILLUSTRIOUS LEGACY As a result of a lifetime of remarkable achievements, Houssay was showered with numerous accolades. In addition to being recognised by the Nobel Foundation, he received honorary degrees and distinctions from multiple prestigious academic institutions such as Harvard, Cambridge, Oxford and the University of Paris. He was also the recipient of the 1960 Dale Medal, the highest honour in the field of endocrinology. But it was his unique amalgam of ingenuity, diligence, personal integrity and devotion to education that comprises the true testament to his legacy as a human being. Moreover, notwithstanding a lifetime of purpose and triumph, Houssay remained humble. An admirer quoted him as saying that "a major enemy of science and the truth is chauvinism, which wants us to believe that we have reached the summit and that there is nothing more we need to achieve". To this day, such infectious passion continues to inspire those familiar with the legacy of Bernardo Houssay.

\section{BIBLIOGRAPHY}

- Encyclopaedia Britannica Online. Bernardo Alberto Houssay [online]. Available at: http://www.britannica.com/EBchecked/topic/273279/ Bernardo-Alberto-Houssay. Accessed December 17, 2015.

- The Nobel Foundation. Bernardo Houssay - Biographical [online]. Available at: http://nobelprize.org/nobel_prizes/medicine/laureates/1947/ houssay-bio.html. Accessed December 17, 2015

- The Nobel Foundation. Nobel Lecture: The Role of the Hypophysis in Carbohydrate Metabolism and in Diabetes [online]. Available at: http:// nobelprize.org/nobel_prizes/medicine/laureates/1947/houssay-lecture. html. Accessed December 17, 2015.

- Whonamedit? A dictionary of medical eponyms. Bernardo Alberto Houssay [online]. Available at: http://www.whonamedit.com/doctor.cfm/1976.html. Accessed December 17, 2015.

- Wikipedia. Bernardo Houssay [online]. Available at: http://en.wikipedia. org/wiki/Bernardo_Houssay. Accessed December 17, 2015. 